\title{
OCCURRENCE OF MUSHROOM DIVERSITY IN CHHATTISGARH PLAINS, NORTHERN HILLY REGIONS AND BASTAR PLATEAU OF CHHATTISGARH STATE
}

Thakur M.P., Shukla C.S. and Jha D.

Indira Gandhi Krishi Vishwavidyalaya Raipur (Chhattisgarh) India Email: mp_thakur@yahoo.com

\begin{abstract}
Seventy five mushroom flora were collected from Chhattisgarh Plains and Bastar Plateau of Chhattisgarh State during survey of mushroom fungi conducted during monsoon season in the year 2005 and 2006. These cultures were purified, some of them were sent to Directorate of Mushroom Research, Solan (H.P.) for further maintenance and some specimens were preserved in formalin. The mushroom flora commonly encountered during survey were: Agaricus sp. Tuber sp., Russula, Boletus, Volvariella, Lactarius, Lepiota etc. During the extensive survey of Chhattisgarh Plains and Northern Hilly Regions in 2005, 25 mushroom fungi and their species during monsoon season were collected from different substrates. Two species of Termitomyces and Russula were predominantly observed from most of the locality. During survey of mushroom fungi from Bastar Plateau of Chhattisgarh in 2006, 50 mushroom fungi were collected and identified during monsoon season. Out of these, 20 fleshy fungi were edible, 23 were non edible and Amanita citrina was poisonous. Other mushroom fungi viz., Boletus lipidus, Clavaria sp, Collybia platyphylla, Collybia acerbata, Clitocybe geotropa, Gromphidius vicidus, Hydrophorus protensis, Lactarius picinus, Lapiota sp., Maramuss rcorodomius, Pholiota apida, Russula crescens, Scleroderma verrucorum, Termitomyces robustus, Tuber spp., Volvariella volvacia, Volvariella sp., Xylaria ploymorpha and Xylaria sp., were found to grow widely on natural substrate.
\end{abstract}

Keywords: Mushroom fungi, Edible, Habitat, Substrate, Poisonous

\section{Introduction:}

The diversity of climatic conditions prevalent in India made this country a natural habitat of a number of mushrooms. There are over 2000 species of edible fungi known to man out of 10,000 species of macrofungi. Watling and Gregory (1980) predicted that since India is richer in flowering plants than any other country of its size, the fungal wealth of India is also expected to be equally diverse. But, no concerted efforts have been made for any detailed study of natural mushroom flora in different parts of the country till today, although some sporadic attempts were made by some workers around the country (Verma, 1997). Similar is the situation in European countries, where the Agarics mycota is largely known, the fungi in many wet tropical forests have never been investigated and more than 20 to $40 \%$ of the species are undescribed. In India, some efforts have been made into the identification of the country's mushroom flora occurring in the diverse biogeographical regions of the country. Attempts were made to survey the areas mostly from South India, North West Himalayas and Eastern part but the North
India including M.P., U.P. and Chhattisgarh have received lesser attention (Shukla, 2005, Thakur et al., 2005). More than 283 species are reported to be the available in India. But, the systematic approach to study the available mushroom flora is still lacking. It is often a difficult proposition to record the morphological details of the collected specimens in its fresh form due to evanescent nature of most of the species. If a standard procedure for collection in adopted, it will be easy to identify these fungi. It requires extensive and intensive surveys to complete the cataloguing of our genetic resources of mushroom. Attempts have to be made to obtain them in pure cultures so as to conserve them in vitro and in vivo. These efforts need to be made at the earliest, so that these important organisms are saved before they are lost due to deforestation and other environmental degradation taking place in our country. Recently, a Mushroom Gene Bank has started functioning at Directorate of Mushroom Research (ICAR), Solan (H.P.) where a sum of 350 mushroom cultures are maintained which includes Agaricus, Pleurotus and other mushroom species. In the present paper, an attempt was made to 
survey the wild edible / non edible / medicinal / poisonous mushroom flora from different agro climatic conditions of Chhattisgarh state with respect to their substrate and place of occurrence and suggest some ways and means to conserve them from erosion.

\section{Materials and methods:}

Chhattisgarh is divided into three agroclimatic zones viz., Chhattisgarh Plains, Northern Hilly regions and Bastar Plateau. Chhattisgarh Plain has vast forest covers including three wild life sanctuaries viz., Sitanadi, Udanti and Barnavapara. Of these, Sitanadi wild life sanctuary is a unique one in the sense that it is a sub tropical forest but the kinds of flora and fauna, it has equivalent to a temperate forest. Most of the flora and fauna of this forest including mushroom flora is unattended and unexplored. North hilly region including Manpat of Surguja distt, which is at higher altitude, had typical mushroom flora, which needs to be conserved and exploited. Bastar plateau is one, which is predominated by thick forest covers and most of the area is still unattended and unexplored. Sporadic attempts have been made in Chhattisgarh in the past to collect, conserve, identify and maintain the mushroom flora available so for. These efforts were made under All India Co-ordinated Mushroom Improvement Project of ICAR operating at Indira Gandhi Agricultural University, Raipur since 1988. A survey for the occurrence of wild mushroom flora in Chhattisgarh Plains, Northern Hilly regions was done in July, 2005 and for Bastar Plateau in JulyAugust, 2006. The area under survey were the districts of Raipur, Bilaspur, Ambikapur, Raigarh and Jashpur Nagar, Kanker, Kondagaon and Jagdalpur. The Survey was made mainly on the way to different places. Both sides of the roads at irregular intervals extending from the roadside to $1 / 2 \mathrm{~km}$ inside were surveyed and the kinds of flora observed were collected, isolated and preserved in formalin as wet preservation.

\section{Results:}

During the extensive survey of Chhattisgarh Plains and North Hilly Regions, 25 mushroom fungi and their species during monsoon season were collected from different substrates. All these mushroom fungi were found associated mainly in termite mounds, soil, wood logs, tree trunk, leaf litter etc. Two species of Termitomyces and Russula were most predominantly observed from most of the locality (Table 1). However, during survey of Bastar Plateau, 50 mushroom fungi were collected and identified during monsoon season (Table 2). Out of these, 20 fleshy fungi were edible, 23 were non edible, five were medicinal and Amanita citrina was poisonous. Some of the species were collected, identified and deposited at National Research Centre for Mushroom, Solan (H.P.). All these fungi were found mainly from soil, wood logs, bamboo tree trunk, leaf litter. Fleshy fungi particularly mushrooms have been identified as articles of food from ancient times. Mushrooms have delicate flavours and have been considered as potential source of proteins, amino acids, vitamins and minerals. Several fleshy fungi appear during rainy season in grass land, abandoned areas and forest on decaying organic matter. The naturally grown fleshy fungi are collected by tribes, consumed by them as well as sold in local market. In all, 75 mushroom flora were collected and preserved in formalin. The mushroom flora commonly encountered during survey were: Agaricus sp. Tuber sp., Russula, Boletus, Volvariella, Lactarius, Lepiota etc. During the extensive survey of Chhattisgarh forest nineteen fleshy fungi viz., Boletus lipidus, Clavaria sp, Collybia platyphylla, Collybia acerbata, Clitocybe geotropa, Gromphidius vicidus, Hydrophorus protensis, Lactarius picinus, Lapiota sp., Maramuss rcorodomius, Pholiota apida, Russula crescens, Scleroderma verrucorum, Termitomyces robustus, Tuber spp., Volvariella volvacia, Volvariella sp., Xylaria ploymorpha and Xylaria sp., were found to grow widely on natural substrate. Out of these seven i.e., Clitocybe geotropa, Lactarius picinus, Marasnius acorodonius, Russula apida, Russula crescens, Termitomyces robustus, Tuber $s p$. Volvariella volvacea and Volvariella $s p$. were edible and consumed by local people. 
There were many mycorrhizal mushroom species which have been used as a food source by people traditionally from the wild and these species don't just grow on soil or wood but associate mutualistically with the roots of various host plants (Lakhanpal, 1995). These mycorrhizal mushrooms are actually fruit bodies of ectotomycorrhizal fungi associated with roots of sal plants and bamboo tree trunk in Chhattisgarh. Since, the mycorrhizal mushrooms can not be grown indoors, hence for some of them techniques have been standardized to cultivate them outdoors in the field / forest associating them with them specific host plants. Around 5000 species of fungi are known to form ectomycorrhize in the generaa Amanita, Tricholoma, Boletus, Cortinarius, Russula, Gomphidius, Cantharellus, Suillus, Hebeloma, Laccaria, Lactarius, Rhizopogon, Scleroderma and Pisolithus. Some of these mushroom genus are also reported from Chhattisgarh during our survey (Thakur et al., 2011). The edible mycorrhizal mushrooms are doubly beneficial. They are a source and income and increment to people and plants, respectively. Hence, these wild edible mushroom species need to be studied and researched for their biology, ecology and social aspects, particularly in relation to their role in stabilizing the forest ecosystem. Due to deforestation or environmental degradation the existence of these mushrooms may be put into danger. Hence, attempts are required to conserve them in situ.

Table-1: Survey of mushroom fungi from Chhattisgarh Plains and North Hilly Regions of Chhattisgarh State

\begin{tabular}{|l|l|l|l|l|}
\hline $\begin{array}{l}\text { S. } \\
\text { No. }\end{array}$ & $\begin{array}{l}\text { Common } \\
\text { name }\end{array}$ & $\begin{array}{l}\text { Scientific } \\
\text { name }\end{array}$ & Location & Habitat \\
\hline 1. & $\begin{array}{l}\text { Kanki } \\
\text { Phutu }\end{array}$ & $\begin{array}{l}\text { Podabrella } \\
\text { microcarpa }\end{array}$ & $\begin{array}{l}\text { College } \\
\text { campus }\end{array}$ & $\begin{array}{l}\text { Termite } \\
\text { mounds }\end{array}$ \\
\hline 2. & - & $\begin{array}{l}T . \\
\text { sulphuricum }\end{array}$ & $\begin{array}{l}\text { Damia, } \\
\text { Pali } \\
\text { Ambikap } \\
\text { ur road }\end{array}$ & Soil \\
\hline 3. & - & Amanita sp. & $\begin{array}{l}\text { Morga, } \\
\text { Navapara }\end{array}$ & Leaf litter \\
\hline 4. & Munda & $\begin{array}{l}\text { Termitomyces } \\
\text { potu } \text { (Cultured) }\end{array}$ & $\begin{array}{l}\text { Damia, } \\
\text { Pali }\end{array}$ & Leaf litter \\
\hline 5. & - & Lactarius sp. & $\begin{array}{l}\text { Damia, } \\
\text { Pali }\end{array}$ & $\begin{array}{l}\text { Leaf litter, } \\
\text { root trunk }\end{array}$ \\
\hline 6. & Haldu & Russula sp. & Damia, & Leaf litter \\
\hline
\end{tabular}

\begin{tabular}{|c|c|c|c|c|}
\hline & phutu & & Pali & \\
\hline 7. & - & $\begin{array}{l}\text { Polyporus } \\
\text { spp. }\end{array}$ & Katghora & Wood log \\
\hline 8. & Black ear & $\begin{array}{l}\text { Auricularia } \\
\text { sp. }\end{array}$ & Morga & Wood log \\
\hline 9. & $\begin{array}{l}\text { Chharkon } \\
\text { i phutu }\end{array}$ & $\begin{array}{l}\text { Astreaus } \\
\text { hygromatricus }\end{array}$ & Navapara & $\begin{array}{l}\text { Sandy soil } \\
\text { under sal } \\
\text { plantation }\end{array}$ \\
\hline 10. & Alu phutu & Tuber sp. & Morga & Sandy soil \\
\hline 11. & $\begin{array}{l}\text { Bhigora } \\
\text { phutu }\end{array}$ & $\begin{array}{l}\text { Termitomyces } \\
\text { clypeatous }\end{array}$ & $\begin{array}{l}\text { Morga } \\
\text { Ambikap } \\
\text { ur }\end{array}$ & $\begin{array}{l}\text { Termite } \\
\text { mounds }\end{array}$ \\
\hline 12. & $\begin{array}{l}\text { Bhigora } \\
\text { phutu }\end{array}$ & $\begin{array}{l}\text { Termitomyces } \\
\text { heimii }\end{array}$ & Morga & $\begin{array}{l}\text { Termite } \\
\text { mounds }\end{array}$ \\
\hline 13. & $\begin{array}{l}\text { Bhigora } \\
\text { phutu }\end{array}$ & $\begin{array}{l}\text { Termitomyces } \\
\text { spp. }\end{array}$ & Raigarh & $\begin{array}{l}\text { Termite } \\
\text { nest }\end{array}$ \\
\hline 14 & $\begin{array}{l}\text { Chikora } \\
\text { phutu }\end{array}$ & $\begin{array}{l}\text { Termitomyces } \\
\text { spp. }\end{array}$ & Udaipur & $\begin{array}{l}\text { Termite } \\
\text { nest }\end{array}$ \\
\hline 15 . & $\begin{array}{l}\text { Patera } \\
\text { phutu }\end{array}$ & $\begin{array}{l}\text { Termitomyces } \\
\text { spp. }\end{array}$ & Morga & $\begin{array}{l}\text { Sandy soil } \\
\text { with } \\
\text { grasses }\end{array}$ \\
\hline 16. & - & Russula spp. & Katghora & Leaf litter \\
\hline 17. & - & Russula sp. & Morga & Wood \\
\hline 18. & - & Pleurotus sp. & Udaipur & Soil \\
\hline 19. & - & Boletus sp. & Morga & Leaf litter \\
\hline 20 & - & $\begin{array}{l}\text { Thellophorace } \\
\text { ae }\end{array}$ & Morga & $\begin{array}{l}\text { Wood of } \\
\text { Dhora tree }\end{array}$ \\
\hline 21. & - & $\begin{array}{l}\text { Laccaria } \\
\text { laccata }\end{array}$ & Morga & Leaf litter \\
\hline 22. & - & Flammula sp. & $\begin{array}{l}\text { Khajurin } \\
\text { ala }\end{array}$ & Leaf litter \\
\hline 23. & - & Volvaria sp. & Manpatt & $\begin{array}{l}\text { Soil (Rich } \\
\text { in humus) }\end{array}$ \\
\hline 24. & - & $\begin{array}{l}\text { Volvariella } \\
\text { volvacea }\end{array}$ & Raigarh & $\begin{array}{l}\text { Paddy } \\
\text { straw heap }\end{array}$ \\
\hline 25. & - & $\begin{array}{l}\text { Ganoderma } \\
\text { lucidum }\end{array}$ & Raigarh & Tree trunk \\
\hline
\end{tabular}


Table-2: Survey of mushroom fungi from different districts of Bastar Plateau of Chhattisgarh State

\begin{tabular}{|c|c|c|c|c|c|}
\hline Sr No. & Scientific name & $\begin{array}{c}\text { Common } \\
\text { name }\end{array}$ & Location & Habitat & Edibility \\
\hline 1. & Agrocybe erebia & - & Tirathgarh & On soil & $\mathrm{E}$ \\
\hline 2. & Amanita citrina & - & - & - & $\mathrm{P}$ \\
\hline 3. & Armillaria mellea & - & - & - & $\mathrm{E}$ \\
\hline 4. & Astreaus hygrometricus & - & - & - & $\mathrm{M}$ \\
\hline 5. & Auricularia $s p$ & - & Narayanpur & On wood logs & $\mathrm{E}$ \\
\hline 6. & Boletus $s p$ & - & Tirathgarh & On soil & $\mathrm{E}$ \\
\hline 7. & Bovista apendicellata & - & - & & $\mathrm{NE}$ \\
\hline 8. & Calocybe $s p$ & - & $\begin{array}{c}\text { Tirathgarah/ } \\
\text { Makdi }\end{array}$ & On wood & $\mathrm{E}$ \\
\hline 9. & Cantharellus $s p$ & Banspihari & Boribeda & On bamboo trunk & $\mathrm{E}$ \\
\hline 10. & Calvatia cyanthiformis & - & & & $\mathrm{E}$ \\
\hline 11. & Clavaria fumosa & - & Bhanpuri & & $\mathrm{NE}$ \\
\hline 12. & Clavaria $s p$ & - & & & $\mathrm{N}$ \\
\hline 13. & Clitocybe gestrpoa & - & & & $\mathrm{E}$ \\
\hline 14. & Crepodorus $s p$ & - & Bhanpuri & & $\mathrm{N}$ \\
\hline 15. & Cyathus limbatus & - & & & $\mathrm{M}$ \\
\hline 16. & Daldunia concentrica & & & & $\mathrm{M}$ \\
\hline 17. & Ganoderma lucidum & - & Makdi \& Kondagao & On died wood logs & $\mathrm{M}$ \\
\hline 18. & Ganoderma sp & - & - & & $\mathrm{M}$ \\
\hline 19. & Goeastrum fimbriatom & - & - & & $\mathrm{NE}$ \\
\hline 20 & Hygrocybe marchee & - & Makdi & & $\mathrm{E}$ \\
\hline 21. & Hypholoma udum & - & Tirathgarh & On soil & $\mathrm{E}$ \\
\hline 22. & Hypoxylon ftagiformal & - & Narayanpire Tirathgarh & & \\
\hline 23. & Incrustoporia semipileta & - & & & \\
\hline 24. & Laccaria laccata & - & & & \\
\hline 25. & Lactarius aceverimus & - & Bastar & & \\
\hline 26. & Lactarius vellereus & - & Bangdongri & & \\
\hline 27. & Lepista $s p$ & - & Makdi & & \\
\hline 28. & Microglossum viride & - & Bhanpuri & & \\
\hline 29. & Nalanla farinalens & - & Bhanpuri & & \\
\hline 30. & Omphalina ericetorum & - & Bhanpuri & & \\
\hline 31. & Panaiolina foenislcie & - & Bhrambela & & \\
\hline 32. & Pleurotus florida like & - & Narayanpur & & $\mathrm{E}$ \\
\hline 33. & Pleurotus sajar caju like & - & Narayanpur & & $\mathrm{E}$ \\
\hline 34. & Pleurotus stramonius like & - & Bhanpuri & & $\mathrm{E}$ \\
\hline 35. & Podoscypha muttzonata & - & Kondagoon & & \\
\hline 36. & Polyporus Varius & - & Narayanpur & On soil & \\
\hline 37. & Ramaria formosa & - & Bangdangri & On wood logs & \\
\hline 38. & Rozites caperata & - & & & \\
\hline 39. & Russula aeruginla & - & & & $\mathrm{E}$ \\
\hline 40. & Russula apida & - & Jagdalpur & & $\mathrm{E}$ \\
\hline 41. & Russula atropurea & - & Tirathgarh & On soil & $\mathrm{E}$ \\
\hline 42. & Russula Mairei & - & & On soil & $\mathrm{E}$ \\
\hline 43. & Russula norvegica & - & Tirathgarh & On soil & \\
\hline 44. & Scleroderma Verrucosum & $\begin{array}{c}\text { Gharkoniph } \\
\text { uty }\end{array}$ & Tirathgarh & & $\mathrm{E}$ \\
\hline 45. & Stereum $s p$ & - & Bangdongri & & \\
\hline 46. & Stropharia Semiglobata & - & Tirathgarh & & \\
\hline 47. & Termitomyces heimii & - & Bhanpuri & & $\mathrm{E}$ \\
\hline 48. & Trametus versicolor & - & Bangdangri & & \\
\hline 49. & Tuber $s p$ & - & Tirathgarh/Bastar & On soil & $\mathrm{E}$ \\
\hline 50. & Volvariella sp like & - & Bhanpuri/Baster & & $\mathrm{E}$ \\
\hline
\end{tabular}

E-Edible (20), NE - Not Edible (23), Medicinal (m) - 5, Edible Fair (EF) -1 - P-1

$\mathrm{NC}=$ Not Confirmed edibility

Discussion: Seventy five mushroom flora were collected from Chhattisgarh Plains and Bastar Plateau of Chhattisgarh State during survey of mushroom fungi conducted during monsoon season in the year 2005 and 2006. Most of these flora have also been reported 
by Thakur et al (2011), Sharma et al (2012), Sarbhoy (1997) during survey of mushroom fungi under AICRP on Mushroom at Raipur during 1997-2004. Some of the mushroom flora commonly encountered during survey were: Termitomyces, Russula, Agaricus sp. Tuber sp., , Boletus, Volvariella, Lactarius, Lepiota etc (Anonymous, 1997-98, Anonymous, 2000-2001, Anonymous, 20012002). During the extensive survey of Chhattisgarh Plains and North Hilly Regions, 18 mushroom fungi and their species during monsoon season were collected from different substrates. Many of these fungi like Termitomyces spp. and others were also reported by Kumar et al., 1991. Two species of Termitomyces and Russula were predominantly observed from most of the locality.

\section{Conclusion:}

Seventy five mushroom flora were collected from Chhattisgarh Plains, Northern Hilly regions and Bastar Plateau of Chhattisgarh State during survey of mushroom fungi conducted during monsoon season in the year 2005 and 2006. Many of them were edible, non edible, medicinal and poisonous.

\section{References:}

Anonymous (1997-98). Annual Progress Report of AICMIP - Raipur Centre. Deptt. of Plant Pathology, IGKV, Raipur.

Anonymous (2000-2001). Annual Progress Report of AICMIP - Raipur Centre. Deptt. of Plant Pathology, IGKV, Raipur.

Anonymous (2001-2002). Annual Progress Report of AICMIP - Raipur Centre, Deptt. of Plant Pathology, IGKV, Raipur.

Kumar, S.M.; Shukla, C.S. and Agrawal, K.C. (1991). Survey of Mushroom in Chhattisgarh region of Madhya Pradesh. Indian Mushrooms, 1991 pp. 6-7.

Lakhanpal, T.N. (1995). Production technology of mycorrhizal mushrooms. In : History, infrastructure and achievements. In : Advances in Horticulture, Vol. 13 (mushroom) eds. Chadha and Sharma, Malhotra Publishing House New Delhi. pp. 155-170.

Sarbhoy, A.K. (1997). Biodiversity and biosystemics of Agarics. In : Advances in Mushroom Biology and Production. Proceeding of the Indian Mushroom Conference - 1997 (eds. Rai, Dhar and
Verma), Mushroom Society of India National Research Centre for Mushroom, Solan (H.P.). pp. 31-38.

Sharma, D.; Thakur, M.P. and Kotasthane, A.S. (2012). Survey, collection, isolation, and characterisation of Ganoderma spp. from Chhattisgarh. Vegetos, 25(1):102-110.

Shukla, R.v. (2005). Wild edible mycorrhizal mushrooms of Chhattisgarh. In: National Mushroom Workshop on "Awareness creation on biodiversity and conservation of mushrooms" organised by Indira Gandhi Krishi Vishwavidyalaya, Raipur from December, 1-2,2005, p.4.

Thakur,M.P.; Shukla, C.S.; Yadav, V.K. (2005). Mushrooms wealth of Chhattisgarh, their conservation ansd exploitation. In: National Mushroom Workshop on "Awareness creation on biodiversity and conservation of mushrooms" organised by Indira Gandhi Krishi Vishwavidyalaya, Raipur from December, 1-2,2005, p.3.

Thakur, M.P.; Shukla, C.S and Yadav, V.K. (2011). Biodiversity and conservation of mushroom in Chhattisgarh region. In : Microbial Biotechnology and Ecology (eds. Deepak Vyas, G.S.Paliwal, P.K.Khare and R.K.Gupta), Daya Publishing House, New Delhi, pp. 320-341.

Verma, R.N. (1997). Recent advances in Mushroom Research in India. In : Advances in Mushroom Biology and Production. Proceedings of the Indian Mushroom Conference 1997 eds. Rai, Dhar and Verma, Mushroom Society of India. National Research Centre for Mushroom, Solan (H.P.) pp. 1-30.

Watling, R. and Gregory, N.M. (1980) Larger fungi from Kashmir. Nova Hedwigia 32: 494- 564. 